\title{
PICTORIAL RIDDLE: PENGARUHNYA TERHADAP DOMAIN KOGNITIF SISWA PADA POKOK BAHASAN GETARAN DAN GELOMBANG
}

\section{PICTORIAL RIDDLE: THE EFFECT ON STUDENT COGNITIVE DOMAINS IN VIBRATION AND WAVE}

\author{
Nanda Febriyanti ${ }^{1}$, Widya Wati ${ }^{2}$ \\ ${ }^{1,2}$ Pendidikan Fisika Universitas Islam Negeri Raden Intan Lampung \\ e-mail: nanda.maniesz@yahoo.com
}

Diterima: 4 Oktober 2018, Disetujui: 7 November 2018, Dipublikasikan: 30 November 2018

\begin{abstract}
The purpose of this study was to determine the effect of Pictorial Riddle learning model on Physics students learning outcomes of class VIII SMPNI Seputih Agung on the vibration and waves material. The research method used was a quasi exsperiment design with nonequivalent control group design. The survey result revealed that the normality test of the experimental class $L_{\text {count }}=0,1557$ and class control $L_{\text {count }}=0,1211 L_{\text {table }}=0,172$. Terms of normality test $L_{\text {count }}<L_{\text {table }}$ then normality distributed data. To test the homogeneity of $F_{\text {count }}<F_{\text {table }}=$ 1,0064 1,69 then the data homogeneous. Test Hypotheses obtained $t_{\text {count }}>t_{\text {table }}=4,83>2,01$ means that there are significant Pictorial Riddle learning model to the outcomes of students subject matter Physics vibration and waves in class VIII SMPN1 Seputih Agung.
\end{abstract}

Abstrak:Tujuan penelitian ini adalah untuk mengetahui model Pictorial Riddle terhadap hasil belajar kognitif fisika siswa kelas VIII SMPN1 Seputih Agung pada materi getaran dan gelombang. Metode penelitian yang digunakan adalah quasi exsperiment design dengan desain nonequivalent control group design. Hasil penelitian diketahui bahwa uji normalitas pada kelas eksperimen $\mathrm{L}_{\text {hitung }}=0,1557$ dan kelas kontrol $\mathrm{L}_{\text {hitung }}=0,1211$ sedangkan $\mathrm{L}_{\text {tabel }}=0,172$. Syarat uji normalitas $\mathrm{L}_{\text {hitung }}<\mathrm{L}_{\text {tabel }}$ maka data tersebut terdistribusi normal. Untuk uji homogenitas $\mathrm{F}_{\text {hitung }}<\mathrm{F}_{\text {tabel }}=1,0064<1,69$ maka data homogen. Uji hipotesis didapatkan $\mathrm{t}_{\text {hitung }}>\mathrm{t}_{\text {tabel }}=4,83>2,01$ artinya, terdapat pengaruh signifikan pembelajaran Pictorial Riddle terhadap hasil belajar peserta didik kelas VIII SMPN1 Seputih Agung pada pokok bahasan getaran dan gelombang.

(C) 2018 Unit Riset dan Publikasi Ilmiah FTK UIN Raden Intan Lampung

Kata Kunci: Getaran dan Gelombang, Hasil Belajar, Model Pictorial Riddle.

\section{PENDAHULUAN}

Pendidikan merupakan sarana penting untuk meningkatkan kualitas sumber daya manusia dalam menjalani keberlangsungan suatu bangsa.

Belajar adalah suatu proses yang dilalui peserta didik untuk memperoleh pengalaman baru melalui mengalami atau latihan. Untuk memperoleh prestasi/hasil belajar yang baik, proses pembelajaran harus dilakukan dengan baik dan tepat. Hasil belajar yang bermutu hanya mungkin dicapai melalui proses belajar yang bermutu (Fayakun, 2015).
Proses belajar mengajar merupakan suatu proses serangkai perbuatan pendidik dan peserta didik atas dasar hubungan timbal balik yang berlangsung dalam situasi edukatif untuk mencapai tujuan tertentu (Kusumah, 2015). Proses belajar bisa terjadi dimana saja dan kapan saja, baik dilingkungan sekolah, rumah, maupun masyarakat. Perubahan tingkah laku peserta didik dapat diketahui dari hasil belajar yang didapatkan, baik pada ranah pengetahuan (kongnitif), sikap (afektif), maupun keterampilan (psikomotor). 
Mata pelajaran Fisika merupakan mata pelajaran yang ditakuti oleh para peserta didik. (Afifah, Ayu, \& Murniati, 2013)

Fisika merupakan salah satu mata pelajaran dalam rumpun sains yang sangat erat kaitannya dengan kehidupan sehari-hari manusia (Saregar, 2016). Pembelajaran Fisika adalah pembelajaran tentang gejalagejala alam, langit dan bumi (alam sekitar), dengan tujuan utama untuk mencari keteraturan dalam pengamatan manusia pada alam sekitarnya. Fisika menjelaskan berbagai gejala fisis fenomena yang terjadi di alam, baik secara teori maupun perhitungan. (Diani, 2015)

Menurut hakikatnya, fisika adalah proses dan produk. Proses artinya prosedur untuk menemukan produk fisika (fakta, konsep, prinsip, teori, atau hukum) yang dilakukan melalui langkah-langkah ilmiah (identifikasi masalah, merumuskan hipotesis, merancang eksperimen, mengumpulkan dan menganalisis data, dan menarik kesimpulan). Hal ini senada dengan pendapat Pristiadi Utomo, bahwa fisika sebagai salah satu bidang ilmu pengetahuan alam menyediakan berbagai pengalaman belajar untuk memahami konsep dan proses sains. Untuk itu pembelajaran fisika hendaknya juga sesuai dengan hakikat fisika.

Pembelajaran Fisika bisa dimulai dari diri pendidik dengan memberikan pengajaran yang lebih mudah dipahami dan dimengerti oleh peserta didik, pemilihan model, dan media pembelajaran membantu peserta didik untuk lebih mudah memahami materi pembelajaran. Model pembelajaran yang diterapkan harus sesuai dengan situasi, kondisi dan kebutuhan peserta didik. Yang tidak kalah penting dalam pembelajaran adalah pemilihan media pembelajaran, media pembelajaran yang interaktif akan membantu proses penyampaian informasi atau materi dengan baik dan mudah dimengerti. Media pembelajaran membantu memantapkan pengetahuan pada benak para peserta didik serta menghidupkan pelajaran yang dapat mempermudah pemahaman siswa. (Diani, 2016)
Salah satu pembelajaran terkini yang dapat dilakukan untuk memperbaiki proses pembelajaran yaitu dengan menggunakan model Pictorial Riddle. Pictorial Riddle adalah suatu proses pembelajaran yang menggunakan gambar atau peragaan di papan tulis, papan poster, atau layar kemudian guru mengajukan pertanyaan yang berkaitan dengan gambar untuk membangkitkan motivasi belajar peserta didik dalam diskusi kelompok kecil atau kelompok besar, melalui penyajian. (Yuswanti, 2011)

Dengan penggunaan gambar, diharapkan penyampaian materi pengajaran menjadi lebih jelas dan lebih mudah dicerna karena membantu peserta didik belajar dengan menggunakan indera penglihatan, disamping itu pembelajaran akan lebih meningkatkan daya tarik peserta didik. (Kristianingsih, 2010)

Rendahnya hasil belajar peserta didik ini disebabkan oleh pemilihan model dan media pembelajaran yang tidak sesuai. Dapat dilihat bahwa model pembelajaran dapat berpengaruh terhadap hasil belajar peserta didik, memilih suatu model mengajar, harus sesuai dengan realitas yang ada dan situasi kelas yang ada, serta pandangan hidup yang akan dihasilkan dari proses kerjasama dilakukan antara guru dan peserta didik. (Jlhad, A \& Haris, 2012)

Salah satu materi fisika yang sangat penting adalah Getaran dan Gelombang. Materi ini menjelaskan tentang gejala getaran, gelombang, hubungan frekuensi dengan periode serta aplikasi dalam kehidupan sehari-hari. Pembelajaran dengan materi ini diharapkan siswa mampu meningkatkan hasil belajar.

Tujuan dari penelitian ini adalah mendeskripsikan hasil belajar siswa (hasil belajar kognitif) setelah diberi perlakuan berupa model pembelajaran Pictorial Riddle. 


\section{LANDASAN TEORI}

\section{Pembelajaran IPA}

Belajar menurut pandangan B.F Skinnr (195) dalam buku metodologi pembelajaran IPA merupakan adaptasi atau penyesuaian tingkah laku yang berlangsung secara progresif. Belajar dipahami sebagai suatu perilaku jadi belajar merupakan perubahan peluang terjadinya respons (Asih Widi W \& Eka Sulistiyawati, 2014). Belajar juga merupakan usaha yang dilakukan manusia untuk mencapai tujuan yang telah ditentukan. Proses belajar dapat terjadi secara sengaja maupun tidak sengaja, yang kesemuanya itu mempunyai keuntungan dan mudah diamati. Belajar menurut piaget adalah proses perubahan konsep. Dalam proses tersebut, peserta didik selalu membangun konsep baru melalui asimilasi dan akomodasi skema mereka. Oleh karena itu, belajar merupakan proses yang terus menerus, tidak berkesudahan.

Fisika adalah ilmu pengetahuan yang paling mendasar, karena berhubungan dengan prilaku dan struktur benda (Giancoli, 2001). Fisika adalah ilmu eksperimental. Fisika merupakan materi, energi, dan fenomena atau gejala alam, baik yang bersifat makroskopis (berukuran besar) maupun yang bersifat mikroskopis (berukuran kecil) (Primavera Citra Risqi Ika, 2014). Dalam belajar Fisika, yang pertama dituntut adalah kemampuan untuk memahaman konsep, prinsip maupun hukum-hukum, kemudian diharapkan peserta didik mampu menyusun kembali dalam bahasanya sendiri sesuai dengan tingkat kematangan dan perkembangan intelektualnya.

\section{Model Pembelajaran Pictorial Riddle}

Model pembelajaran untuk mengembangkan aktivitas peserta didik dalam diskusi kelompok kecil maupun besar, melalui penyajian masalah yang disajikan dalam bentuk ilustrasi. Suatu ridlle biasanya berupa gambar di papan tulis, papan poster, atau maupun diproyeksikan dalam bentuk transparansi, kemudian guru mengajukan pertanyaan yang berkaitan dengan ridlle. Metode ini memberikan kesempatan kepada peserta didik untuk memecahkan masalah yang telah disampaikan sebelumnya, oleh guru melalui gambar, peragaan, atau situasi yang sesungguhnya.

Sintak pembelajaran Pictorial Riddle dapat diterapkan dengan mengikuti tahaptahap berikut ini: (Sitti, Awal, Ahmad, Yani, \& Bunga Dara, Amin, 2016)

1. Pendidik menampilkan masalah dalam bentuk gambar. Misalnya sebuah gambar anak kecil sedang bermain ayunan.

2. Peserta didik mengamati tampilan gambar yang mempubliskan masalah.

3. Merumuskan permasalahn yang terdapat dalam gambar

4. Peserta didik mengumpulkan data dari rangkaian jawaban gambar yang ditampilkan

5. Setelah itu peserta didik melakukan diskusi terkait gambar yang telah ditampilkan

6. Peserta didik mempresentasikan hasil diskusi yang telah dilakukan dalam kelompoknya.

\section{Hasil Belajar}

Belajar bukan suatu tujuan tetapi merupakan suatu proses untuk mencapai tujuan. Belajar itu sendiri merupakan suatu proses dari seseorang yang berusaha untuk memperoleh suatu bentuk perubahan prilaku yang relative menetap. Belajar merupakan langkah- langkah atau prosedur yang ditempuh. Bukti bahwa seseorang telah belajar ialah terjadinya perubahan tingkah laku pada seseorang tersebut.

Hasil belajar dinyatakan dalam klasifikasi yang dikembangkan oleh Benyamin $S$ Bloom, dalam sistem pendidikan nasional rumusan tujuan pendidikan mengacu pada klasifikasi hasil belajar dari Bloom yang secara garis besar yaitu aspek kognitif, aspek afektif dan aspek psikomotor (Widodo \& Widayanti, 2013). Dalam penelitian ini hasil 
belajar yang diteliti adalah hasil belajar kognitif.

\section{METODE PENELITIAN}

Metode penelitian yang di gunakan adalah quasi eksperimental (Eksperimen Semu). Model desain eksperimen ini mempunyai kelompok kontrol, tetapi tidak dapat berfungsi sepenuhnya untuk mengontrol variabel-variabel luar yang mempengaruhi pelaksanaan eksperimen (Sugiyono, 2013). dalam penelitian ini digunakan desain nonequivalent control group design, desain ini hampir sama dengan pretest-posttes countrol group desain hanya pada desain ini kelompok eksperimen maupun kelompok konrol tidak dipilih secara random. Populasi tersebut terdiri atas 8 kelas yaitu, IPA (A,B,C,D,E,F,G,H). Sampel dalam penelitian ini hanya diambil pada peserta didik kelas VIII IPA E sebagai kelas eksperimen dan VIII IPA C sebagai kelas kontrol dengan jumlah peseta didik pada setiap kelas 30 peserta didik.

Instrumen penelitian yang digunakan pada penelitian ini terdiri dari soal pretest dan posttest untuk mengetahui pencapaian hasil belajar siswa pada aspek kognitif berupa soal pilihan jamak terdiri dari 20 soal dengan empat alternatif jawaban pada setiap butir soalnya. (Asyhari \& Hartati, 2015; Diani, Yuberti, \& Syafitri, 2016)

Instrument yang digunakan selanjutnya adalah lembar observasi yang bertujuan untuk melihat aktivitas peserta didik yang sedang terjadi secara runtut dari awal sampai akhir dan untuk melihat keterlaksanaan model pembelajaran. Data observasi diukur menggunakan skala liket.

Teknik Analisis data yang dilakukan adalah uji normalitas, uji homogenitas, uji hipotesis dengan uji t dan uji hasil observasi. Uji effect size menggunakan rumus: (Hake, 2002; Saputro \& Latifah, 2018)
Keterangan:

$$
d=\frac{m_{A}-m_{B}}{\left[\left(s d_{A}^{2}+s d_{B}^{2}\right) / 2\right]^{1 / 2}}
$$

d : effect size

$\mathrm{m}_{\mathrm{A}} \quad$ : nilai rata-rata kelas eksperimen

$m_{B} \quad$ : nilai rata-rata kelas kontrol

$\operatorname{sd}_{\mathrm{A}} \quad$ : standar deviasi kelas eksperimen

$\operatorname{sd}_{\mathrm{B}} \quad$ : standar deviasi kelas control

\section{HASIL DAN PEMBAHASAN}

Masing - masing kelas terdiri dari 30 peserta didik. Kelas eksperimen diterapkan model pembelajaran Pictorial Riddle, sedangkan di kelas kontrol diterapkan model konvensional. dari 30 soal yang telah diuji cobakan didapatkan 20 soal untuk tes akhir. Hasil belajar posstes yang diperoleh oleh kelompok eksperimen dengan 20 soal mencapai rata- rata 79,1 sedangkan kelompok kontrol 64,7. Nilai maksimal kelas eksperimen yang diperoleh peserta didik adalah 85, dan minimal adalah nilai 65 . Sedangkan kelompok kontrol nilai maksimal 70, dan nilai minimum 60. Lebih jelasnya dapat dilihat pada table 1 dibawah ini:

Tabel 1. Distribusi hasil belajar postes kelompok eksperimen dan kelompok control.

\begin{tabular}{llll}
\hline \multirow{2}{*}{ No } & \multirow{2}{*}{ Perolehan } & Eksperimen & Kontrol \\
\cline { 3 - 4 } & & $\mathbf{f}$ & $\mathbf{f}$ \\
\hline $\mathbf{1}$ & 50 & - & 2 \\
$\mathbf{2}$ & 55 & - & 3 \\
$\mathbf{3}$ & 60 & - & 3 \\
$\mathbf{4}$ & 65 & 2 & 9 \\
$\mathbf{5}$ & 70 & 3 & 13 \\
$\mathbf{6}$ & 75 & 5 & - \\
$\mathbf{7}$ & 80 & 8 & - \\
$\mathbf{8}$ & 85 & 12 & - \\
\hline
\end{tabular}

Berdasarkan tabel 1, diketahui bahwa nilai Fisika kelas Eksperimen dan kelas kontrol berbeda, penerapan model pembelajaran Pictorial Riddle di SMPN 1 Seputih Agung mampu mempengaruhi hasil belajar peserta didik.

Uji normalitas dilakukan untuk mengetahui data berdistribusi normal atau tidak. Hasil uji normalitas disajikan pada tabel 2 . 
Tabel 2. Uji Normalitas

\begin{tabular}{lllll}
\hline $\begin{array}{l}\text { N } \\
\text { o }\end{array}$ & Kelompok & Lhitung & Ltabel & $\begin{array}{l}\text { Keputusan } \\
\text { Uji }\end{array}$ \\
\hline $\mathbf{1}$ & Eksperimen & 0,155762 & 0,1726 & Ho diterima \\
$\mathbf{2}$ & Kontrol & 0,121138 & 0,1726 & Ho diterima
\end{tabular}

Dari hasil uji normalitas diketahui bahwa data terdistribusi normal karena $\mathrm{L}_{\text {hitung }}<\mathrm{L}_{\text {tabel }}=\quad 0,155762<0,1726 \quad$ dan $0.121138<0,1726$.

Selanjutnya dilakukan uji homogenitas. Dengan taraf signifikan $\alpha=0,05$ diperoleh Ftab = 1,69 (interpolasi) dan dari hasil perhitungan diperoleh Fhit $=1,006540698$ Berdasarkan hasil tersebut terlihat bahwa Fhit < Ftab. Hal ini berarti bahwa HO diterima. Jadi dapat disimpulkan bahwa sampel berasal dari populasi yang homogen artinya peserta didik dari kelas sampel memiliki kemampuan yang setara. Kehomogenitasan sampel ini menyempurnakan prasyarat yang dibutuhkan untuk melakukan uji hipotesis menggunakan uji t-tes.

Setelah data dikatakan normal dan homogen, maka hipotesis dapat diuji untuk mengetahui adakah pengaruh model pembelajaran Pictorial Riddle terhadap hasil belajar Fisika peserta didik pada materi Getaran dan Gelombang di kelas VIII SMPN1 Seputih Agung. Untuk mengetahui ada tidaknya perbedaan perlakuan maka digunakan rumus uji t. jika nilai thitung $>$ ttabel berarti terdapat pengaruh perlakuan. Berdasarkan dari data yang didapat bahwa thitung $=5,036$ dan ttabel $=2,01$. Karena thitung > ttabel $=5,036>2,01$ maka Ho ditolak dan $\mathrm{H} 1$ diterima. Ini menunjukkan bahwa terdapat pengaruh model pembelajaran Pictorial Riddle terhadap hasil belajar Fisika peserta didik dikelas VIII SMPN 1 Seputih Agung pada materi Getaran dan gelombang.
Selanjutnya, dari hasil uji hipotesis yang diperoleh. Kemudian dilakukan uji effect size. Hasil yang diperoleh adalah 0,1827.

Teknik pengumpulan data selanjutnya yang digunakan adalah dengan menggunakan teknik observasi. Hasil observasi disajikan pada tabel berikut:

Tabel 3. Hasil Keterlaksanaan Pembelajaran Pictorial Riddle

\begin{tabular}{cccc}
\hline No & Pertemuan & Persentase & Keterangan \\
\hline 1 & I & 0,87 & Baik \\
2 & II & 0,91 & Sangat Baik \\
3 & III & 0,92 & Sangat Baik \\
\hline
\end{tabular}

Hasil keterlaksanaan pembelajaran dengan persentase 0,87 pada pertemuan pertama, persentase 0,91 pada pertemuan kedua dan persentase 0,92 pada pertemuan ketiga. Dilihat dari tabel diatas persentase keterlaksanaan pada pertemuan per pertemuan yang telah dilakukan selama pembelajaran meningkat dari baik sampai menjadi sangat baik.

\section{KESIMPULAN DAN SARAN Kesimpulan}

Berdasarkan hasil analisis dan pengolahan data maka disimpulkan bahwa terdapat pengaruh model pembelajaran Pictorial Riddle terhadap hasil belajar peserta didik pada materi getaran dan gelombang kelas VIII SMPN1 Seputih Agung, thitung $=5,036$ dan ttabel $=2,01$. Karena thitung $>$ ttabel $=5,036>2,01$ maka Ho ditolak dan H1 diterima. Selanjutnya, diperoleh hasil uji effect size sebesar 0,1827. Hasil ini menunjukkan kan bahwa model pembelajaran Pictorial Riddle mempengaruhi hasil belajar peserta didik. Peningkatan hasil belajar kognitif tersebut juga menunjukkan adanya suatu usaha dari peserta didik untuk lebih mengerti akan materi yang sedang dipelajari. Usaha tersebut terlihat dalam kegiatan pembelajaran yang aktif, peserta didik selalu bertanya, dan menggali informasi lain selain yang telah didapatkan dari guru. 


\section{Saran}

Berdasarkan hasil penelitian, maka dapat disarankan kepada pendidik atau calon pendidik untuk melakukan alternatif pembelajaran. Salah satunya dengan menggunakan model Pictorial Riddle, yang dapat berpengaruh terhadap hasil belajar peserta didik. Dari hasil penelitian ini juga dapat diadakan lanjutan tentang pembelajaran dengan model Pictorial Riddle untuk materi atau topik yang berbeda.

\section{DAFTAR PUSTAKA}

Afifah, N., Ayu, N., \& Murniati, N. (2013). Penerapan Pendekatan Kontekstual Menggunakan Media Video Untuk Meningkatkan Hasil Belajar Fisika Pada Kelas XI RPL 1 SMK N 8 Semarang. Seminar Nasional 2nd Lonttar Physics Forum, 72, 1.

Asih Widi W \& Eka Sulistiyawati. (2014). Metodologi Pembelajaran IPA. Jakarta: PT. Bumi Aksara.

Asyhari, A., \& Hartati, R. (2015). Implementasi Pembelajaran Fisika SMA Berbasis Inkuiri Terbimbing Terintegrasi Pendidikan Karakter untuk Meningkatkan Hasil Belajar Siswa pada Materi Cahaya dan Optika. Jurnal Ilmiah Pendidikan Fisika Al-Biruni, 4(1), 2.

Diani, R. (2015). Upaya Meningkatkan Aktivitas dan Hasil Belajar Fisika Siswa Dengan Menggunakan Strategi Pembelajaran Aktif Tipe Inquiring Minds Want To Know Di Smp Negeri 17 Kota Jambi. Jurnal Ilmiah Pendidikan Fisika Al-Biruni, 4(1).

Diani, R. (2016). Pengaruh Pendekatan Saintifik Berbantukan LKS terhadap Hasil Belajar Fisika Peserta Didik Kelas XI SMA Perintis 1 Bandar Lampung. Jurnal Ilmiah Pendidikan Fisika AlBiruni, 5(1). https://doi.org/10.24042/jpifalbiruni.v5 i1.108

Diani, R., Yuberti, Y., \& Syafitri, S. (2016). Uji Effect Size Model Pembelajaran Scramble dengan Media Video terhadap
Hasil Belajar Fisika Peserta Didik Kelas X MAN 1 Pesisir Barat. Jurnal Ilmiah Pendidikan Fisika Al-BiRuNi 05, 5(2).

Fayakun. (2015). Efektivitas Pembelajaran Fisika Menggunakan Model Kontekstual (CTL) dengan Metode Predict, Observe, Explain terhadap Kemampuan Berpikir Tingkat Tinggi. Jurnal Pendidikan Fisika Indonesia, 11(1).

https://doi.org/10.15294/jpfi.v11i1.400 3

Giancoli, D. C. (2001). Fisika (Edisi Keli). Jakarta: Erlangga.

Hake, R. R. (2002). Relationship of individual student normalized learning gains in mechanics with gender, highschool physics, and pretest scores on Mathematics and Spatial Visualization. Physics Education Research Conference, 8(August 2002), 1-14.

Jlhad, A \& Haris, A. (2012). Evaluasi Pembelajaran. Yogyakarta: Multi Pressido.

Kristianingsih, D. (2010). Peningkatan Hasil Belajar Siswa Melalui Model Pembelajaran Inkuiri dengan Metode Pictorial Riddle pada Pokok Bahasan Alat-Alat Optik di SMP. Jurnal Pendidikan ..., 6(1), 10-13.

Kusumah, D. H. (2015). Pengembangan Media Pembelajaran Video Tutorial Facebokk Untuk Meningkatkan Hasil Belajar Siswa Pada Mata Pelajaran Pemasaran Online Di Smk Negeri 3 Surakarta, (November).

Primavera Citra Risqi Ika, D. (2014). Pengaruh Media Audio Visual Terhadap Hasil Belajar Siswa Kelas XI Pada Konsep Elastisitas. Prosiding Seminar Nasional Pendidikan IPA FITK UIN Syarif Hidayatullah Jakarta, (September), 122-129.

Saputro, T., \& Latifah, S. (2018). Efektivitas

Metode Pembelajaran Quantum Learning terhadap Kemampuan Berpikir Tingkat Tinggi Peserta Didik Kelas X MA Nurul Islam Gunung Sari Ulubelu Tanggamus. Indonesian 
Journal of Science and Mathematics Education, 1(2), 29-37.

Saregar, A. (2016). Pembelajaran Pengantar Fisika Kuantum dengan Memanfaatkan Media PhET Simulation Dan LKM Melalui Pendekatan Saintifik : Dampak Pada Minat Dan Penguasaan Konsep Mahasiswa. Jurnal Ilmiah Pendidikan Fisika Al-Biruni, 5(1), 53-60. https://doi.org/10.24042/jpifalbiruni.v5 i1.105

Sitti, Awal, U. M. M., Ahmad, Yani, U. N. M., \& Bunga Dara, Amin, U. N. M. (2016). Jurnal Pendidikan Fisika Universitas Muhammadiyah Makassar Peranan Metode Pictorial Riddle Terhadap Penguasaan Konsep. Jurnal Pendidikan Fisika Universitas
Muhammadiyah Makassar, 4(2), 249266.

Sugiyono, S. (2013). Metode Penelitian Pendidikan. Bandung: Alfabeta.

Widodo, \& Widayanti, L. (2013). Promblem Based Learning Pada Siswa Kelas VIIA MTs Negeri Donomulyo Kulon Progo Tahun Pelajaran 2012/2013. Fisika Indonesia, XVII(49), 32-35.

Yuswanti, Y. (2011). Pengunaan Media Gambar Untuk Meningkatkan Hasil Belajar Siswa Pada Pembelajaran IPS Di Kelas IV SD PT . Lestari Tani Teladan ( LTT ) Kabupaten Donggala. Jurnal Kreatif Tadulako Online, 3(4), 185-199. 